\title{
Opiniões políticas e sentimentos partidários dos eleitores brasileiros ${ }^{1}$
}

\author{
Yan de Souza Carreirão \\ Departamento de Ciência Política \\ Universidade Federal de Santa Catarina
}

\begin{abstract}
Resumo: Este artigo tem como foco central as opiniões políticas dos eleitores brasileiros que manifestam sentimentos em relação aos partidos políticos e o objetivo principal é verificar se há algum tipo de "estrutura" nas suas opiniões políticas, bem como as possíveis variações ao longo do tempo. Os dados proveêm de quatro surveys nacionais realizados em diferentes momentos: 1990, 1997, 2002 e 2007. A análise mostra que as opiniões políticas dos eleitores que manifestam sentimentos por diferentes partidos são mais diferenciadas entre si no início do que ao final do período aqui estudado, o que parece se dever, em boa parte, aos sinais emitidos pelos partidos, de maior indiferenciação entre si ao final do período.
\end{abstract}

Palavras-chave: sentimentos partidários; opiniões políticas; partidos políticos; ideologia; representação.

\begin{abstract}
This article focuses on the political opinions of the Brazilian voters who express partisan feelings. The main goal is to verify if there is a structure in the political opinion of these voters which manifest partisan feelings and if there is variation along time as regards these opinions. The analysis is carried out based on four national surveys applied in different moments: 1990, 1997, 2002 and 2007. The analysis reveals that the opinions of the voters who express feelings for different parties were more differentiated at the beginning of the period established for the present study than at the end of this same period. This seems to be the reflect, in part, of the signals issued by the parties which hold smaller differentiation between each other at the end of the period.
\end{abstract}

Keywords: partisan feelings; political opinions; political parties; ideology; representation.

\footnotetext{
${ }^{1}$ Este trabalho é resultado parcial de pesquisa que tem apoio do Conselho Nacional de Desenvolvimento Científico e Tecnológico (CNPq), na forma de Bolsa de Produtividade (Proc. 308411/2007-2).
} 


\section{Introdução}

Este trabalho tem como foco central os sentimentos dos eleitores brasileiros em relação aos partidos políticos, manifestados em pesquisas de opinião. Alguns autores têm apontado certa relevância não só das manifestações de preferência (ou identificação) partidária, mas também da rejeição aos partidos, na decisão do voto. Outros minimizam esta influência e questionam o próprio significado das manifestações de identidade partidária, já que elas não teriam durabilidade, estabilidade ao longo do tempo. O presente trabalho, embora não tenha como tema central a possível influência dos sentimentos partidários sobre o voto, mostra indícios que apontam para esta possível influência. Estes indícios justificam o objetivo principal deste estudo, que é verificar se há algum tipo de "estrutura" nas opiniões dos eleitores que manifestam sentimentos partidários. Verificar, por exemplo, se "eleitores petistas" (os que manifestam "preferência" pelo PT) têm opiniões diferentes dos "eleitores pefelistas", e se há variações, ao longo do tempo, nestas opiniões. Para isso, utilizamos quatro surveys nacionais realizados em diferentes momentos: 1990, 1997, 2002 e $2007^{2}$.

A principal hipótese testada é que a auto-identificação ideológica e as opiniões políticas dos eleitores que manifestam sentimentos por diferentes partidos são mais diferenciadas entre si no início do que ao final do período mencionado. Esta hipótese deriva de uma hipótese norteadora mais ampla, qual seja, a de que as ideologias políticas têm tido seu peso reduzido na dinâmica do processo político nacional e, portanto, no funcionamento do sistema partidário. Se, no plano internacional, o ponto de inflexão no sentido de uma menor polarização ideológica foi o declínio dos regimes socialistas do Leste Europeu, que teve como marco

\footnotetext{
2 O survey de 1990 foi realizado através de um consórcio entre o Departamento de Ciência Política da USP, o Cedec (Centro de Estudos de Cultura Contemporânea) e o Datafolha. Aplicado entre 03 e 04/03/1990 a 2480 eleitores, com sorteio aleatório dos domicílios e estratificação por região, sexo, idade e nível socioeconômico. (Foi obtido junto ao Cesop - Centro de Estudos de Opinião Pública / Unicamp: pesquisa com a seguinte identificação: Avaliação Sarney / Expectativa Collor II - Datafolha / Brasil 90.Mar-00219. Disponível em: <http://www.cesop.unicamp.br/site/htm/busca/php>). O survey de 1997 foi aplicado pelo Núcleo de Opinião Pública da Fundação Perseu Abramo, entre 15/11 e 14/12/2007, a uma amostra nacional de 2700 eleitores; margem de erro de 2\%, embora muitas questões tenham sido aplicadas apenas à metade da amostra, elevando a margem de erro para 3\%. (Foi utilizada uma versão, com esclarecimentos sobre a amostra, obtida junto ao Cesop). O Estudo Eleitoral Brasileiro (ESEB) - 2002 foi uma pesquisa empreendida pelo DataUFF e pelo Centro de Estudos de Opinião Pública (Cesop / Unicamp), com o patrocínio da CAPES e da FAPESP. O questionário foi aplicado entre 31/10 e 28/12/2002; amostra probabilística (2513 eleitores), sem reposição, em três estágios (município, setor censitário e domicílio), com margem de erro aproximada de 3,2\%. O LAPOP Brasil (2007) é um survey aplicado a partir de um consórcio entre a Universidade de Goiás, a Vanderbilt University e o LAPOP - Projeto de Opinião Pública da América Latina a 1200 eleitores. Nossos agradecimentos a estas instituições (e a seus colaboradores), por tornarem os dados disponíveis para pesquisa.
} 
simbólico principal a queda do muro de Berlim, no Brasil, este processo se cristaliza com a chegada de Lula e do PT ao poder central do país. Como pleiteia Singer (2000), durante as décadas de oitenta e noventa do século passado, o PT foi a espinha dorsal ideológica do sistema partidário, em torno da qual os demais partidos (e boa parte da sociedade civil e do eleitorado) se alinhavam (contra ou a favor). Certamente, no decorrer desse período, já foram ocorrendo mudanças nas idéias e comportamentos dos membros deste partido com relação a seus posicionamentos iniciais. Mas, estas mudanças só ficaram muito nítidas, para o eleitorado e também para muitos dos estudiosos e dos atores políticos relevantes, a partir de 2002, já na formação da chapa e na campanha eleitoral de Lula, explicitando-se ainda mais a partir do início do seu primeiro mandato como presidente da República.

A composição partidária e ideológica dos membros e partidos que formaram o governo (incluindo a direção do Banco Central), a manutenção da espinha dorsal da política econômica do governo anterior, a formação da base de apoio no Congresso Nacional, com uma coalizão bem mais heterogênea ideologicamente do que o padrão anterior das administrações municipais e estaduais petistas, sinalizaram claramente para uma diluição da rigidez ideológica que costumava ser associada aos discursos e ações petistas, resultando em coalizões formadas em plenário, nas votações nominais da Câmara Federal, menos consistentes ideologicamente quando comparadas ao período anterior ao governo Lula (SANTOS, 2006). Nossa hipótese é que também tenha aumentado a inconsistência ideológica das coligações eleitorais e das migrações partidárias após $2002^{3}$.

Parte da diferenciação do PT em relação aos demais partidos, na percepção de parcela significativa do eleitorado e mesmo de atores políticos relevantes, estava associada a uma diferenciação também no plano ético (não importando aqui saber se esta percepção sobre o partido correspondia ou não à "verdade"). Mas, após o conjunto de episódios envolvendo o PT em atividades no mínimo suspeitas, do ponto de vista ético (das quais o episódio do "mensalão" é o mais notável), também esta percepção se desvanece.

As diferenças entre esquerda e direita se diluem; se as pesquisas mostram que parte relevante do eleitorado ainda manifesta preferências e rejeições partidárias, é possível que estas estejam cada vez menos associadas a programas e idéias defendidos pelos diferentes partidos. Além da possibilidade de que elas se devam a associações, na percepção dos eleitores, entre as siglas e seus principais líderes, é provável também que se devam, em grande medida, à avaliação que os diferentes segmentos do eleitorado fazem dos partidos, especialmente a partir de suas gestões, quando comandando governos relevantes. Nestas avaliações,

\footnotetext{
${ }^{3}$ Embora não conheçamos dados nacionais que permitam comprovar esta hipótese, ela é corroborada por dados relativos a Santa Catarina (CARREIRÃO, 2006).
} 
pesariam especialmente os resultados (mais do que as "diretrizes políticas") das políticas econômica, social e de segurança pública (no caso de governos estaduais), mas também os aspectos ligados à moralidade pública nas ações dos principais membros do partido nestes governos. Isso explicaria, por um lado, o aumento da preferência pelo PT entre os mais pobres e nos estados do nordeste (VEIGA, 2007) . já que as políticas econômica e social do governo Lula são bem avaliadas por estes segmentos - e a manutenção em 2006 da percepção já predominante antes do PT como o partido "que mais defende a justiça social", especialmente entre os eleitores mais pobres (VENTURI, 2006). Poderia explicar também, por outro lado, a redução da preferência pelo PT na região sudeste e entre os eleitores mais escolarizados, bem como o aumento da porcentagem do eleitorado que percebe o PT como o "partido que tem mais políticos que só pensam neles mesmos" e "partido que tem mais políticos corruptos" (VENTURI, 2006). Outra hipótese daí derivada (que, infelizmente, não pode ser testada diretamente através dos dados de que dispomos) é a de que diminuiu o componente de rejeição ideológica ao PT e à Lula (componente que representava cerca de metade da rejeição a Lula no survey de 1997 da Fundação Perseu Abramo) e de que aumentou o componente de rejeição por avaliação da dimensão ética dos comportamentos dos membros do partido e do governo.

Se todas essas hipóteses fossem corroboradas, do ponto de vista analítico, a dimensão ideológica - que tem servido para orientar boa parte da literatura recente sobre o comportamento governamental e partidário (na formação de ministérios e na disciplina partidária), sobre o comportamento parlamentar (nas coalizões em plenário e no que se refere à migração partidária, diferenciando os parlamentares dos partidos segundo sua posição ideológica) e sobre o comportamento eleitoral . perderia grande parte de sua capacidade heurística. O comportamento parlamentar seria mais bem compreendido a partir da dicotomia governo-oposição do que pelo contínuo direita-esquerda; o custo da inconsistência ideológica seria cada vez menos relevante na análise dos cálculos das decisões partidárias sobre coligações eleitorais e coalizões governamentais; o comportamento eleitoral mais bem compreendido por variáveis como avaliação de desempenho de partidos, governos e candidatos, com base em atributos como competência administrativa, honestidade, ou mesmo a defesa de interesses de certos grupos sociais (como os "pobres", ou "trabalhadores"), mas mesmo este último atributo teria pouca relação com o posicionamento dos partidos, governos e candidatos em um eixo direita-esquerda. Outra conseqüência, que aqui nos interessa, é a de que as opiniões políticas dos eleitores com preferência ou rejeição a diferentes partidos seriam cada vez menos diferenciadas entre si. 
Enfim, a hipótese específica deste estudo deriva de hipótese norteadora mais ampla, de que estamos passando, especialmente após o início do primeiro mandato do presidente Lula, por um processo de redução da polarização ideológica da política brasileira, seguindo um processo mais amplo, em escala internacional, cujo ponto de inflexão se deu a partir do final da década de 1980, com a queda de grande parte dos regimes comunistas ${ }^{4}$. Isso tem se manifestado no comportamento de políticos, partidos e governos e se refletido no comportamento do eleitorado e de organizações da sociedade civil. Do ponto de vista acadêmico, resulta daí que as variáveis ideológicas perdem espaço para outras variáveis na explicação do comportamento dos eleitores, parlamentares, partidos e governos.

\section{Revisão da literatura}

Quanto ao debate sobre identificação partidária na literatura internacional, Carreirão e Kinzo (2004) apresentam um balanço, confrontando os enfoques da teoria psico-sociológica do voto e da teoria da escolha racional sobre o tema, bem como mostram que a avaliação predominante é a de que está havendo uma diminuição da relevância dos partidos na decisão de voto na maioria das democracias contemporâneas.

No que respeita ao sistema partidário brasileiro, há divergências entre os que apontam baixa influência das preferências partidárias sobre o voto (MENEGUELLO, 1995; SILVEIRA, 1998, PAIVA et al, 2007, entre outros) e os que apontam na direção oposta ou matizam aquelas conclusões (BALBACHEVSKI, 1992; KINZO, 1992; CASTRO, 1994; SINGER, 2000; CARREIRÃO e KINZO, 2004; CARREIRÃO e BARBETTA, 2004; CARREIRÃO, 2007; NICOLAU, 2007) ${ }^{5}$.

Entre os estudos mais recentes, cabe destacar as conclusões de Paiva et al: "no que se refere aos sentimentos partidários, esses já eram pouco significativos em 2002 e tenderam a diminuir em 2006" (PAIVA et al, 2007, p. 405). Além disso, apontam "a dificuldade do eleitorado de diferenciar os partidos... Se o eleitorado não diferencia os partidos, torna-se difícil o estabelecimento de preferências

\footnotetext{
4 Outros processos também têm contribuído para um maior "pragmatismo" dos partidos em suas estratégias de formação de coligações eleitorais e coalizões governamentais: o aumento da distância temporal em relação ao período do regime autoritário mais recente ajuda a diluir a clivagem entre partidos e políticos da situação e da oposição àquele regime (clivagem que em parte se superpõe à clivagem ideológica); o aumento da fragmentação partidária (facilitada pela legislação eleitoral) aumenta a competição eleitoral, estimulando estratégias coligacionistas mais agressivas, em que um eventual custo interno de perder militantes (por insatisfação com a "flexibilidade ideológica" do partido) é compensado pelo aumento nas chances eleitorais.

${ }^{5}$ Alguns destes últimos incluíram a rejeição partidária (além das preferências) na análise.
} 
partidárias minimamente consistentes para balizar a escolha eleitoral". Neste debate, nos parece que um dos questionamentos mais sérios à existência desta influência seja quanto à estabilidade temporal das preferências (ou identidades) partidárias, o que colocaria em questionamento a possível relação de causalidade entre as variáveis (ou seja, o papel que a percepção dos eleitores sobre os partidos políticos teria sobre sua decisão de voto). Castro, referindo-se ao período anterior a 1994 afirma que "os dados sugerem que, pelo menos parte das identificações com os partidos políticos, quando existem, manifestam-se somente no processo eleitoral, talvez orientado pela escolha de candidatos" (CASTRO, 1994, p.168-9). Silveira (1998), a partir de seu estudo com base em entrevistas em profundidade com eleitores, segue este diagnóstico. Rennó (2007) afirma que, no caso brasileiro, há evidências de que a identificação partidária não é durável (estável no tempo). O autor menciona artigo em que "Ames et al (2006), usando dados de painel coletados em duas cidades brasileiras nas eleições de 2002 e, posteriormente, em 2004, encontram que há flutuações substantivas da identificação partidária de eleitores quando medida em momentos diferentes da campanha e entre campanhas" (RENNÓ, 2007, p.268). Mas, o próprio autor reconhece que há necessidade de mais estudos longitudinais para testar esta hipótese novamente.

De outro lado, outros estudos, utilizando análise de correlação simples têm mostrado que a associação entre os sentimentos partidários e o voto dos eleitores é substancial ou moderada para um parcela não desprezível de eleitores (SINGER, 2000; CARREIRÃO e KINZO, 2004, dentre outros). Também estudos que utilizaram análise de regressão logística, com (CARREIRÃO e BARBETTA, 2004; CARREIRÃO, 2007) ou sem (NICOLAU, 2007) a inclusão da rejeição partidária têm pleiteado a relevância dos sentimentos partidários na decisão de voto no Brasil. Como se vê, o debate sobre o tema está longe de se esgotar.

No que se refere às opiniões políticas dos eleitores brasileiros, é significativa a literatura sobre cultura política, que enfatiza a análise de temas como a adesão a valores democráticos, confiança nas instituições e confiança interpessoal, (destacando-se aí os trabalhos de Moisés, Meneguello, Baquero e Borba, dentre outros). Outros estudos têm analisado as possíveis associações entre opiniões políticas, de um lado, e voto ou "identificação ideológica" dos eleitores, de outro (PIERUCCI, 1987 e 1994, PIERUCCI e LIMA, 1991, METTTENHEIM, 1995, SINGER, 2000, ALMEIDA, 2001, CARREIRÃO, 2002, dentre outros). Há ainda importantes estudos acadêmicos sobre atitudes e opiniões políticas mais gerais dos eleitores brasileiros (entre os quais os de LAMOUNIER, 1992; CERVI, 2006; ALMEIDA, 2007). Mas, na forma específica de análise da associação entre sentimentos partidários e opiniões políticas dos eleitores, ou seja, da compreensão das opiniões dos eleitores com preferência (e rejeição) partidária, a produção brasileira, salvo engano, é escassa. O presente trabalho pretende contribuir para minimizar esta lacuna. 


\section{Sentimentos Partidários e Voto}

Vimos que não há consenso na literatura no que se refere à possível influência dos sentimentos partidários manifestados pelos eleitores sobre sua decisão de voto. O questionamento mais sério à existência desta influência é quanto à estabilidade temporal das preferências (ou identidades) partidárias, o que colocaria em questionamento aquela relação de causalidade. Como as evidências da instabilidade são ainda restritas (espacial e temporalmente), são necessários mais testes desta hipótese.

Por outro lado, há indícios de um grau substancial de associação entre as variáveis, aí considerando, no âmbito dos sentimentos partidários, não só as preferências (ou identidades) partidárias, mas também a rejeição a partidos, por parte dos eleitores. A Tabela 1 mostra, para três dos quatro surveys já mencionados $^{6}$, a associação entre o voto nos dois principais candidatos às três últimas eleições presidenciais (1998, 2002 e 2006) e os sentimentos positivos e negativos manifestados pelos eleitores em relação aos partidos destes candidatos (PT e PSDB). Foi criada uma escala que vai da situação mais favorável ao PT (situação 1: sentimento positivo ${ }^{7}$ em relação ao $\mathrm{PT}$ e rejeição ao $\mathrm{PSDB}$ ), à situação mais favorável ao PSDB (situação 7: sentimento positivo em relação ao PSDB e rejeição ao PT), com várias outras situações intermediárias.

\footnotetext{
${ }^{6}$ Esta análise semelhante não foi feita para o survey de 1990 porque não havia ali questão sobre rejeição partidária.

7 Foram considerados como sentimentos positivos as manifestações de preferência partidária (1997 e, para outras análises, 1990), ou a soma das referências ao "partido que representa o eleitor" e ao "partido que o eleitor gosta" (2002 e 2007).
} 
Tabela 1 - Diferença de voto entre candidatos do PT e do PSDB para presidente, segundo sentimentos em relação ao PT e ao PSDB (1998, 2002, 2006)

\begin{tabular}{|c|c|c|c|c|c|c|c|c|c|}
\hline \multirow{2}{*}{$\begin{array}{l}\text { Eleição } \\
\text { (e survey) }\end{array}$} & \multirow{2}{*}{$\begin{array}{l}\text { Diferença de votos, } \\
1^{\circ} \text { turno }\end{array}$} & \multicolumn{7}{|c|}{ Sentimentos em relação ao PT e PSDB * } & \multirow{2}{*}{ Total } \\
\hline & & 1 & 2 & 3 & 4 & 5 & 6 & 7 & \\
\hline \multirow{2}{*}{$\begin{array}{l}\text { 1998: } \\
\text { FPA } \\
1997\end{array}$} & Lula - FHC (\%) & 71 & 57 & 12 & .23 & .50 & .66 & .88 & $\cdot 17$ \\
\hline & Total (N) & 34 & 302 & 32 & 1394 & 296 & 81 & 59 & 2197 \\
\hline \multirow{2}{*}{$\begin{array}{l}\text { 2002: } \\
\text { ESEB } \\
2002\end{array}$} & Lula - Serra (\%) & 86 & 76 & 51 & 16 & 50 & 36 & .66 & 28 \\
\hline & Total (N) & 315 & 330 & 260 & 752 & 259 & 44 & 70 & 2030 \\
\hline \multirow{2}{*}{$\begin{array}{l}\text { 2006: } \\
\text { LAPOP } \\
2007\end{array}$} & Lula - Alckmin (\%) & 86 & 93 & 67 & 49 & 50 & .6 & $\cdot 71$ & 50 \\
\hline & Total (N) & 28 & 261 & 18 & 489 & 66 & 37 & 31 & 930 \\
\hline
\end{tabular}

* Sentimentos em relação ao PT e PSDB: 1 = sentimento positivo em relação ao PT e rejeição ao PSDB; 2 = somente sentimento positivo em relação ao PT; 3 = somente rejeição ao PSDB; $4=$ situações neutras; 5 = somente rejeição ao PT; 6 = somente sentimento positivo em relação ao PSDB; 7 = sentimento positivo em relação ao PSDB e rejeição ao PT.

Foram consideradas "situações neutras" aquelas em que o eleitor não manifestou nenhum sentimento em relação aos dois partidos, ou manifestou o mesmo sentimento (positivo ou negativo) em relação aos dois, ou manifestou sentimentos contraditórios (positivos e negativos, simultaneamente, a um mesmo partido). Pouquíssimos casos correspondem a esta última situação, em cada survey.

Foram desconsiderados na análise os entrevistados que informaram não ter votado, ou que responderam que não se lembravam em quem haviam votado, ou cuja resposta foi "não sabe" ou "não respondeu" à pergunta sobre o voto no $1^{\circ}$ turno da eleição. As porcentagens foram calculadas sobre 0 total dos eleitores (em cada categoria de "sentimentos") que disseram ter votado em algum candidato, em branco ou nulo.

Fontes: Fundação Perseu Abramo, 1997; ESEB 2002; LAPOP-Brasil 2007.

Há, em todos os casos, uma alta associação entre os "sentimentos" manifestados pelos eleitores em relação ao PT e ao PSDB e seu voto. Embora a tabela só mostre os dados para o $1^{\circ}$ turno de cada eleição, em relação à votação no $2^{\circ}$ turno as associações foram ainda maiores: coeficientes de correlação gama variando entre 0,60 e 0,84, para o $1^{\circ}$ turno e entre 0,68 e 0,89, para o $2^{\circ}$ turno, nos diversos surveys ${ }^{8}$. A vantagem do candidato petista (sempre Lula) sobre o peessedebista (FHC, Serra ou Alckmin) diminui claramente à medida que passamos da situação 1 (a mais favorável ao PT e desfavorável ao PSDB) para a situação 7 (mais favorável ao PSDB e desfavorável ao PT). Enquanto entre os eleitores na primeira situação Lula venceria FHC, Serra ou Alckmin por diferenças entre $71 \%$ e $96 \%$, entre os eleitores na situação 7 a inversão é completa: Lula seria derrotado por qualquer destes candidatos por diferenças que variavam entre $66 \%$ e $88 \%$. A única inversão nas tendências de crescimento ou declínio contínuo nas votações dos candidatos, face ao aqui esperado em termos lógicos, ocorreu na passagem da posição 5 para a posição 6, em três das quatro pesquisas. Assim, para a decisão de

\footnotetext{
8 Operacionalizando as variáveis "voto no $1^{\circ}$ turno" e "voto no $2^{\circ}$ turno" com 3 categorias cada ( $1^{\circ}$ turno: 1 = Lula; 2 = outros candidatos + brancos e nulos; 3 = candidato do PSDB; $2^{\circ}$ turno: 1 = Lula; 2 = brancos e nulos; 3 = candidato do PSDB).
} 
voto em um candidato "tucano" pesou mais a rejeição ao PT do que uma manifestação de apreço ao PSDB.

Deve-se ressalvar que as correlações mencionadas foram calculadas com base no conjunto de eleitores, em cada survey, que, simultaneamente, votava em algum candidato (ou em branco ou nulo) e manifestava sentimentos partidários. Aqueles que manifestavam sentimentos partidários que poderiam influenciar seu voto (situações 1, 2, 3, 5, 6 e 7 na Tabela 1), no entanto, representavam percentuais que variavam de $37 \%$ a $63 \%$ dos eleitores para os quais as perguntas (relativas às variáveis em estudo) foram aplicadas, nos diferentes surveys ${ }^{9}$. Ou seja, embora a associação seja alta entre os eleitores que manifestam sentimentos partidários, o impacto global desta variável sobre o voto acaba não sendo tão grande devido ao fato de que os eleitores que manifestam estes sentimentos representam, em média, cerca de $50 \%$ do eleitorado brasileiro ${ }^{10}$.

De toda forma, este é um percentual considerável e, dada a alta associação encontrada neste segmento do eleitorado, julgamos que, enquanto não for testada de forma mais sistemática a hipótese de que estes sentimentos são muito voláteis (eventualmente seguindo sentimentos dos eleitores em relação às principais lideranças políticas de cada partido), vale a pena incluir esta variável nos estudos sobre o comportamento do eleitor brasileiro. Isso justifica, a nosso ver, a análise que segue, sobre a identificação ideológica e as opiniões políticas do conjunto de eleitores que manifestam algum tipo de sentimento em relação aos partidos políticos.

\section{Opiniões políticas dos eleitores com sentimentos partidários}

Esta seção explora as opiniões políticas dos eleitores que manifestam sentimentos partidários. Isso será feito a partir do cruzamento entre suas opiniões (quando possível construindo índices que dão uma medida sintética destas opiniões e atitudes) e seus sentimentos partidários para os quatro surveys utilizados neste artigo. O objetivo é verificar se há diferenças de opiniões (em relação a variados temas políticos) entre os eleitores que manifestam sentimentos (positivos e/ou negativos) pelos principais partidos brasileiros e se estas opiniões variam ao longo

\footnotetext{
9 É necessária esta qualificação, já que em alguns surveys o número de respondentes às questões envolvidas não é igual ao tamanho da amostra: há respondentes que não haviam votado, ou não se lembravam do voto, no momento da aplicação dos questionários; no survey de 1997, a pergunta sobre rejeição só foi aplicada a cerca de metade da amostra.

10 Há muita variação de um survey a outro, em parte devido às diferenças metodológicas nas perguntas relativas aos sentimentos partidários (preferência; partido que representa o eleitor, ou de que ele gosta; perguntas espontâneas e únicas em alguns casos e estimuladas e múltiplas, em outros casos, no caso da rejeição).
} 
do tempo. Este último objetivo é limitado pelas diferenças entre os diferentes surveys. Em primeiro lugar, no que se refere aos sentimentos partidários positivos: enquanto nos dois primeiros a pergunta era sobre preferência partidária ${ }^{11}$, nos outros dois havia perguntas sobre "partido que o representa" e "partido que gosta"; além disso, havia diferenças entre estes dois últimos surveys nestas questões, como visto nas notas 5 e 7. No que se refere aos sentimentos negativos (rejeição) em relação aos partidos, não há dados para o primeiro dos surveys aqui analisados (o de 1990) e há diferenças na formulação das perguntas entre os dois últimos (conforme nota 10). No que se refere às opiniões e atitudes dos eleitores, as perguntas também são diferentes entre todos os surveys. Em alguns é possível trabalhar com vários índices que agregam as respostas a várias perguntas, enquanto em outros isso é muito difícil. De toda forma, mesmo com as limitações apontadas, acreditamos que o estudo possa dar alguma pista sobre a evolução das opiniões dos "eleitores partidários" ao longo dos últimos dezoito anos.

Nos quatro surveys foram feitas diversas perguntas sobre opiniões a respeito de vários temas políticos e sociais. Analisamos a relação entre estas opiniões e os sentimentos (positivos ou negativos) manifestados pelos eleitores em relação aos partidos. Nos dois primeiros surveys, com exceção de um índice de autoritarismo, utilizamos diretamente as respostas a cada uma das questões que visavam "medir" as opiniões políticas dos eleitores ${ }^{12}$. Nos dois últimos foi possível criar índices que sintetizam várias respostas dos entrevistados relativas a uma mesma dimensão de opinião ${ }^{13}$. A análise utilizará o coeficiente de correlação Gama (de Goodman e Kruskal) para verificar o sentido e a intensidade da associação entre as opiniões políticas e os sentimentos partidários ${ }^{14}$. A Tabela 2 mostra as correlações para o survey de 1990.

\footnotetext{
11 Resposta à pergunta: "Qual seu partido preferido?".

12 A quase totalidade das perguntas é do tipo "concorda ou discorda" de uma única frase, cujo núcleo central é apresentado na coluna "opiniões políticas" das tabelas, tornando claro o sentido das perguntas. No caso da pergunta sobre "democracia x ditadura" o enunciado era "com qual das três frases seguintes você concorda mais: 1) a democracia é sempre melhor do que qualquer outra forma de governo"; 2) em certas situações, é melhor uma ditadura do que um regime democrático; 3) tanto faz se o governo é uma democracia ou uma ditadura"?

13 A utilização de índices permite agregar respostas a questões que fazem parte de uma mesma dimensão relativa às opiniões dos eleitores. Desta forma, em vez de trabalharmos com um número muito grande de respostas, conseguimos classificar cada um dos entrevistados (a partir das respostas dadas a uma bateria de questões relativas a uma mesma dimensão) numa escala (na qual varia o índice) e fazer testes de associação entre estas opiniões e outras variáveis de interesse (em nosso caso, os sentimentos partidários dos eleitores).

14 O coeficiente de correlação Gama (de Goodman e Kruskal) é adequado para medir a associação entre duas variáveis ordinais. A preferência (ou indicação do partido que melhor representa o eleitor) e a rejeição partidárias foram agregadas segundo o posicionamento ideológico dos partidos (esquerda, centro, direita). Quanto às opiniões políticas, quando analisadas uma a uma, foram operacionalizadas sempre com três categorias (a partir de respostas do tipo: concorda; depende; discorda), de forma que a primeira correspondia à posição mais democrática, igualitária, participativa, intervencionista (no plano econômico) ou liberal (do ponto de vista moral), enquanto a terceira correspondia ao inverso (posição
} 
CARREIRÃO, Y. S. Opiniões políticas e sentimentos partidários...

\section{Tabela 2 - Correlação entre opiniões políticas e preferência partidária, segundo posicionamento ideológico dos partidos, 1990}

\begin{tabular}{|l|c|c|}
\hline $\begin{array}{l}\text { Pergunta } \\
(\mathbf{1})\end{array}$ & Opiniões políticas & $\begin{array}{c}\text { Coef. } \\
\text { gama }\end{array}$ \\
\hline 29 & Índice de autoritarismo (controle do Estado sobre sociedade) & $\mathbf{0 , 4 1 * *}$ \\
\hline 23 & Democracia x ditadura & $.0,02$ \\
\hline 25 & Minoria deve obedecer maioria, deixando de lado suas idéias & $\mathbf{0 , 1 2 * *}$ \\
\hline 26 & Mudanças: por líder forte x por participação popular & $\mathbf{0 , 2 3 * *}$ \\
\hline $35 a$ & É bobagem mudar leis, porque elas não são respeitadas. & 0,05 \\
\hline $35 \mathrm{~b}$ & Mudanças no Brasil só com violência & 0,04 \\
\hline $35 \mathrm{c}$ & Melhor manter família que acabar com casamento infeliz & $\mathbf{0 , 2 4 * *}$ \\
\hline $35 \mathrm{~d}$ & Volta dos militares ao poder & $\mathbf{0 , 2 8 * *}$ \\
\hline $35 \mathrm{e}$ & Governo, protegendo os pobres, prejudica quem trabalha & $\mathbf{0 , 2 2 *}$ \\
\hline $35 f$ & No capitalismo quem se esforça pode ficar rico & $\mathbf{0 , 2 7 * *}$ \\
\hline $35 \mathrm{~g}$ & País seria melhor se só existisse um partido político & $\mathbf{0 , 2 4 * *}$ \\
\hline $35 \mathrm{~h}$ & Melhor caminho p/ ajudar os pobres é c/ ajuda do governo & $\mathbf{0 , 1 8 * *}$ \\
\hline $35 \mathrm{i}$ & No Brasil só deveriam votar as pessoas com estudo & $\mathbf{0 , 0 4}$ \\
\hline $35 \mathrm{j}$ & Se o país for rico não importa que haja desigualdade social & $\mathbf{0 , 2 9 * *}$ \\
\hline $35 \mathrm{k}$ & A única solução para o país é o socialismo & $\mathbf{0 , 0 3}$ \\
\hline
\end{tabular}

$\left(^{*}\right)$ coef. significativo nível 0,05; $\left(^{* *}\right)$ coef. sig. nível 0,01; demais coef. não significativos.

(1) Números das perguntas no questionário.

Fonte: Cedec-Datafolha - Março 1990 (Universo: Brasil) $(N=2480)$.

Embora com intensidades relativamente baixas, há muitas correlações no sentido esperado (coeficiente positivo): maior preferência partidária por partidos à esquerda entre eleitores mais democráticos, igualitários, participativos ou liberais (em questões morais). A maior correlação $(0,41)$ se dá entre preferência partidária e índice de autoritarismo dos eleitores (Apêndice Metodológico). Para uma percepção mais clara da associação são apresentados na Tabela 3 dados do cruzamento destas duas variáveis.

mais autoritária, menos igualitária, menos participativa, menos intervencionista, no plano econômico e mais conservadora, do ponto de vista moral). Quando utilizados índices (de autoritarismo, nos surveys de 1990 e 1997, e vários outros, nos surveys de 2002 e 2007), estes foram sempre operacionalizados com três categorias: baixo, médio e alto (ver Apêndices Metodológicos 1 a 4). 
Tabela 3 - Preferências partidárias dos eleitores - agregadas conforme os posicionamentos ideológicos dos partidos - segundo o índice de autoritarismo, 1990 (\%)

\begin{tabular}{|l|c|c|c|c|}
\hline Preferência Partidária & \multicolumn{4}{|c|}{ Índice de autoritarismo } \\
\cline { 2 - 5 } $\begin{array}{l}\text { segundo posicionamento } \\
\text { ideológico dos partidos }\end{array}$ & Baixo & Médio & Alto & Total \\
\hline Partidos de Esquerda & 51 & 30 & 11 & 32 \\
\hline Partidos de Centro & 25 & 26 & 36 & 28 \\
\hline Partidos de Direita & 24 & 44 & 52 & 39 \\
\hline$(\mathrm{N})$ & $(345)$ & $(389)$ & $(260)$ & $(994)$ \\
\hline
\end{tabular}

Obs: A tabela inclui apenas os eleitores que manifestaram preferência partidária.

Fonte: Cedec-USP-Datafolha - Março 1990 (Universo: Brasil) ( $N=2480$ ). Gama $=0,41$ (sig. = 0,000).

Entre os eleitores menos autoritários (ou seja, aqueles que tendiam a discordar mais em relação à possibilidade de o governo reprimir manifestações de protesto), a preferência maior era por partidos de esquerda (51\%) e a menor era por partidos de direita (24\%); já entre os eleitores mais autoritários (que tendiam a concordar mais em relação à possibilidade de o governo reprimir manifestações de protesto) ocorre o inverso ( $52 \%$ manifestavam preferência por partidos de direita, contra apenas $11 \%$ que preferiam partidos de esquerda $)^{15}$.

$\mathrm{Na}$ Tabela 4, são apresentados os coeficientes de correlação entre opiniões políticas dos eleitores, de um lado, e as preferências e rejeições partidárias, de outro, para o survey da Fundação Perseu Abramo, de $1997^{16}$.

\footnotetext{
15 A Tabela Anexa 1 mostra os dados de forma mais detalhada, segundo o partido preferido (e não agregando os partidos segundo seu posicionamento ideológico, como faz a Tabela 3).

${ }^{16}$ A rejeição partidária é operacionalizada a partir da indicação do nome de um partido em resposta à pergunta "existe algum partido em que você não votaria? Qual?".
} 
CARREIRÃO, Y. S. Opiniões políticas e sentimentos partidários...

\section{Tabela 4 - Correlação entre opiniões políticas e sentimentos partidários, segundo posicionamento ideológico dos partidos, 1997}

\begin{tabular}{|c|c|c|c|}
\hline \multirow{2}{*}{$\begin{array}{l}\text { Per- } \\
\text { gunta } \\
\text { (1) }\end{array}$} & \multirow{2}{*}{ Opiniões políticas } & \multicolumn{2}{|c|}{ Sentimento Partidário } \\
\hline & & Preferência & Rejeição \\
\hline 44 & $\begin{array}{c}\text { Índice de autoritarismo } \\
\text { (controle Estado sobre sociedade) }\end{array}$ & $0,23^{* *}$ & $0,39 * *$ \\
\hline 37 & Socialismo como solução para os problemas sociais & $0,15^{*}$ & 0,06 \\
\hline 38 & Democracia $\mathrm{x}$ ditadura & 0,01 & 0,06 \\
\hline 39 & Minoria deve obedecer maioria, deixando de lado suas idéias & $0,17^{*}$ & $0,25 * *$ \\
\hline 42 & Mudanças: por líder forte x por participação popular & 0,05 & 0,02 \\
\hline $43 a$ & $\begin{array}{c}\text { Para manter a ordem, as leis, mesmo injustas, devem ser } \\
\text { obedecidas }\end{array}$ & 0,07 & $\cdot 0,04$ \\
\hline $43 b$ & Mudanças no Brasil só com revolução ou pela força & 0,08 & ND \\
\hline $43 c$ & Política é para profissionais (deputados; senadores) & 0,11 & ND \\
\hline $43 d$ & $\begin{array}{c}\text { Não há solução para problemas sociais sem reforma agrária } \\
\text { radical }\end{array}$ & $-0,01$ & ND \\
\hline $43 e$ & País funcionaria melhor $\mathrm{c} /$ a volta dos militares ao poder & $0,20 *$ & ND \\
\hline $43 f$ & $\begin{array}{l}\text { O que a sociedade produz deveria ser distribuído com } \\
\text { igualdade entre todos }\end{array}$ & 0,07 & 0,18 \\
\hline $43 g$ & $\begin{array}{c}\text { O melhor para o país é que o governo se envolva o menos } \\
\text { possível com as atividades econômicas }\end{array}$ & 0,09 & 0,11 \\
\hline $43 h$ & $\begin{array}{c}\text { Por mais que se queira mudar as coisas, sempre vão existir } \\
\text { ricos e pobres }\end{array}$ & 0,08 & 0,04 \\
\hline $43 i$ & $\begin{array}{c}\text { O movimento dos sem terra está certo em fazer a ocupação } \\
\text { de terras improdutivas }\end{array}$ & $0,16^{*}$ & $0,33^{*}$ \\
\hline
\end{tabular}

Fonte: Fundação Perseu Abramo - Núcleo de Opinião Pública, 1997. ND = Não há dados.

No que se refere às preferências partidárias, várias correlações estatisticamente significativas são no sentido esperado (coeficiente positivo): maior preferência por partidos à esquerda entre eleitores mais democráticos, mais favoráveis ao socialismo, ao direito da minoria se manifestar e à ocupação de terras improdutivas pelo MST. Mas, a intensidade das correlações entre opiniões e preferência partidária é menor do que em 1990. Algumas correlações entre opiniões e rejeição aos partidos tiveram coeficientes maiores de correlação, também no sentido esperado: maior rejeição a partidos de esquerda entre eleitores mais autoritários, menos tolerantes com o direito da minoria de manifestar suas idéias, ou contrários à ocupação de terras pelo MST. O índice de autoritarismo (que, embora construído a partir de questões um pouco diferentes, "mede" uma 
dimensão da opinião semelhante àquela "medida" pelo índice para o survey de $1990)^{17}$ é o que apresenta as maiores correlações com a preferência $(0,23)$ e a rejeição partidária $(0,39)$ dos eleitores. A Tabela 5 mostra o cruzamento com base no qual foi calculado este último coeficiente de correlação.

\section{Tabela 5 - Rejeição aos partidos (agregados conforme seus posicionamentos ideológicos), segundo o índice de autoritarismo, 1997 (\%)}

\begin{tabular}{|l|c|c|c|c|}
\hline $\begin{array}{l}\text { Rejeição aos partidos } \\
\text { segundo } \\
\text { posicionamento } \\
\text { ideológico }\end{array}$ & \multicolumn{4}{|c|}{ Índice de autoritarismo } \\
\cline { 2 - 5 } & Baixo & Médio & Alto & Total \\
\hline Esquerda & 41 & 57 & 69 & 53 \\
\hline Centro & 21 & 24 & 22 & 22 \\
\hline Direita & 39 & 20 & 9 & 26 \\
\hline$(\mathrm{N})$ & $(111)$ & $(76)$ & $(64)$ & $(251)$ \\
\hline
\end{tabular}

$(\mathrm{N}=4935)$ Gama $=0,39$ (sig. $=0,000)$.

Obs: Da subamostra à qual foi aplicada a questão sobre rejeição, a maioria não indicava rejeição a nenhum partido; por isso o número de casos na tabela é tão pequeno.

Fonte: Fundação Perseu Abramo. Núcleo de Opinião Pública (Universo: Brasil), 1997.

A rejeição por partidos de esquerda aumenta (de $41 \%$ para $69 \%$ ) e a rejeição por partidos de direita diminui (de 39\% para 9\%), à medida que passamos dos eleitores menos autoritários para os mais autoritários - no que se refere à concordância com a possibilidade de o governo reprimir greves, sindicatos, censurar órgãos de comunicação, proibir a existência de partidos ou mesmo fechar o Congresso Nacional ${ }^{18}$.

\footnotetext{
17 Ver Apêndice Metodológico 2.

$18 \mathrm{Em}$ todos os quatro surveys um percentual significativo de eleitores ou não tinha uma opinião formada em relação ao tema em pauta, ou não manifestava sentimento (positivo ou negativo) em relação a nenhum partido, levando a que as parcelas da amostra em relação às quais cada um dos coeficientes de correlação foi calculado fossem numericamente pequenas. Isso significa que as conclusões retiradas dos coeficientes de correlação valem apenas para esta parcela do eleitorado que, simultaneamente, tinha uma opinião formada sobre o tema e manifestava o sentimento partidário em análise. Além disso, este baixo número de casos pode afetar o grau de significância das estatísticas calculadas. Este último problema é agravado nos surveys de 1997 e 2007. No de 1997, além destes fatores, acresce que algumas perguntas foram aplicadas apenas a uma parte da amostra; no survey de 2007, o problema é que a amostra foi menor do que nos demais. Na comparação final entre os quatro surveys, tentaremos minimizar os possíveis efeitos dessas especificidades, levando-as, de alguma forma, em consideração.
} 
Os dados referentes às correlações entre os sentimentos partidários dos eleitores e os índices que sintetizam suas opiniões políticas (ver Apêndice Metodológico 3) no Estudo Eleitoral Brasileiro (ESEB), de 2002, são mostrados na Tabela 6.

\section{Tabela 6 - Correlação entre opiniões políticas e sentimentos partidários, segundo posicionamento ideológico dos partidos, 2002}

\begin{tabular}{|c|c|c|}
\hline \multirow{2}{*}{$\begin{array}{l}\text { Índices } \\
\text { (que sintetizam opiniões políticas dos eleitores) }\end{array}$} & \multicolumn{2}{|c|}{ Sentimento Partidário } \\
\hline & $\begin{array}{l}\text { Partido que } \\
\text { representa }\end{array}$ & Rejeição \\
\hline $\begin{array}{l}\text { Autoritarismo } \\
\text { (grau de controle do Estado sobre a sociedade) }\end{array}$ & $0,39 * *$ & $0,13 * *$ \\
\hline Regulação do mercado por parte do Estado & 0,04 & $0,09 * *$ \\
\hline Fechamento do mercado para o exterior & $.0,03$ & $.0,03$ \\
\hline Liberalismo econômico & $-0,01$ & 0,02 \\
\hline Conservadorismo Moral & 0,09 & $0,13 * *$ \\
\hline Clientelismo & $0,26 * *$ & $0,07^{*}$ \\
\hline "Rouba mas faz" & 0,04 & 0,04 \\
\hline
\end{tabular}

$\left({ }^{*}\right)$ coef. signif. nível 0,05; $\left(^{* *}\right)$ coef. signif. nível 0,01; demais coef. não signif. estatisticamente.

Obs: associações estatisticamente significativas estão em negrito.

Fonte: ESEB, 2002.

Há duas correlações positivas com "preferência partidária"19, no sentido esperado: maior "preferência" por partidos à esquerda entre eleitores mais autoritários (com relação à maior aceitação de maior controle da sociedade pelo Estado) clientelistas. Há correlações positivas (mas de baixa magnitude) com rejeição, no sentido esperado: maior rejeição por partidos de esquerda entre eleitores mais autoritários, clientelistas, ou conservadores (em questões morais) e entre os contrários à regulação do mercado por parte do Estado. A Tabela 7 mostra o cruzamento entre o posicionamento ideológico dos partidos que representam o eleitor, segundo o índice de autoritarismo deste último.

19 Embora a pergunta fosse sobre "qual o partido que representa melhor a maneira de pensar" (do eleitor), vamos nos referir aqui à "preferência partidária" do eleitor. Um dos problemas deste estudo, porém, é o fato de que, pelo menos no que respeita aos "sentimentos positivos" manifestados pelos eleitores, os dois primeiros surveys não podem ser comparados, estritamente, com os dois últimos, já que as perguntas formuladas aos eleitores eram diferentes. De toda forma, como os dados não revelam um contraste claro entre os dois primeiros surveys (tomados em conjunto) e os dois últimos (também tomados em conjunto) - o que poderia ser creditado às diferenças de enunciados das questões -, acreditamos que possam dar indícios da evolução das manifestações positivas dos eleitores em relação aos partidos ao longo do tempo. No caso dos "sentimentos negativos", a pergunta sobre "rejeição" foi similar nos três últimos surveys, embora não tenha sido apresentada no primeiro. 
Tabela 7 - Posicionamento ideológico dos partidos que representam o eleitor, segundo o índice de autoritarismo dos eleitores, 2002 (\%)

\begin{tabular}{|l|c|c|c|c|}
\hline Posicionamento & \multicolumn{4}{|c|}{ Índice de autoritarismo } \\
\cline { 2 - 5 } $\begin{array}{l}\text { ideológico dos partidos } \\
\text { que representam o eleitor }\end{array}$ & Baixo & Médio & Alto & Total \\
\hline Esquerda & 82 & 72 & 49 & 70 \\
\hline Centro & 12 & 20 & 38 & 21 \\
\hline Direita & 7 & 9 & 13 & 9 \\
\hline$(\mathrm{N})$ & $(288)$ & $(371)$ & $(196)$ & $(855)$ \\
\hline
\end{tabular}

Gama: 0,39 (Sig. 0,001).

Fonte: ESEB, 2002.

Há, como esperado, um declínio substancial da "preferência" por partidos de esquerda e um aumento da "preferência" por partidos de centro e direita, à medida que passamos dos eleitores menos autoritários para os mais autoritários (ou seja, aqueles que se manifestam mais em acordo com a proibição de protestos contra o governo).

$\mathrm{Na}$ Tabela 8, são apresentadas as correlações entre os sentimentos partidários dos eleitores e os índices que sintetizam suas opiniões políticas (ver Apêndice Metodológico 4) no survey de 2007 (LAPOP-Brasil).

\section{Tabela 8 - Correlação entre opiniões políticas e sentimentos partidários,} segundo posicionamento ideológico dos partidos, 2007

\begin{tabular}{|c|c|c|}
\hline \multirow{2}{*}{$\begin{array}{l}\text { Índices } \\
\text { (que sintetizam opiniões políticas dos } \\
\text { eleitores) }\end{array}$} & \multicolumn{2}{|c|}{ Sentimento Partidário } \\
\hline & $\begin{array}{l}\text { Partido que } \\
\text { representa }\end{array}$ & Rejeição \\
\hline $\begin{array}{l}\text { Autoritarismo } 1 \\
\text { (controle do Estado sobre a sociedade) }\end{array}$ & $-0,03$ & 0,04 \\
\hline $\begin{array}{l}\text { Autoritarismo } 2 \\
\text { (direitos políticos oposição e minorias) }\end{array}$ & 0,05 & $.0,03$ \\
\hline $\begin{array}{l}\text { Autoritarismo } 3 \\
\text { (apoio a golpes de Estado) }\end{array}$ & $-0,20 *$ & 0,12 \\
\hline Apoio à Concentração do Poder Político & $-0,21^{*}$ & $-0,21 * *$ \\
\hline Radicalismo & 0,13 & $\cdot 0,07$ \\
\hline Liberalismo Econômico & $0,22 *$ & 0,06 \\
\hline Participacionismo & 0,03 & $0,12 *$ \\
\hline Igualitarismo & $.0,02$ & 0,06 \\
\hline Conservadorismo Moral & 0,01 & $0,16 *$ \\
\hline Clientelismo & 0,10 & $.0,04$ \\
\hline "Rouba, mas faz" & $\cdot 0,11$ & $.0,01$ \\
\hline
\end{tabular}

Obs: associações estatisticamente significativas estão em negrito.

Fonte: LAPOP-Brasil, 2007. 
Há apenas uma correlação positiva estatisticamente significativa entre os índices e "preferências partidárias": a preferência por partidos de esquerda é proporcionalmente menor entre os eleitores menos liberais em matéria econômica; por outro lado, há duas correlações estatisticamente significativas no sentido inverso ao "esperado": a "preferência" por partidos de esquerda aumenta à medida que passamos dos eleitores que menos apóiam para os que mais apóiam a concentração do poder político nas mãos do presidente ou dos menos para os mais autoritários (ou seja, que mais "apoiariam" eventuais golpes de Estado por parte dos militares) ${ }^{20}$ (Tabelas Anexas 2 e 3).

Quanto à rejeição, as correlações estatisticamente significantes no sentido esperado são fracas: partidos de esquerda tendem a ser mais rejeitados por eleitores menos favoráveis à participação social, ou mais conservadores (do ponto de vista moral). A maior correlação encontrada, porém, é no sentido inverso ao esperado: a rejeição a partidos de esquerda declina entre os eleitores que mais apóiam a centralização do poder político nas mãos do presidente. Em relação a este índice (Apêndice Metodológico 4, item 4.6), os dados relativos aos sentimentos positivos e negativos em relação aos partidos reforçam uma tendência (contrária à esperada inicialmente): a "preferência" quanto a partidos de esquerda aumenta à medida que passamos dos eleitores com baixo aos com alto índice de adesão à concentração do poder político (nas mãos do presidente da República). O inverso ocorre com a rejeição, que é tanto menor em relação aos partidos de esquerda à medida que cresce o índice de adesão à concentração do poder político por parte dos eleitores ${ }^{21}$.

\footnotetext{
20 Rigorosamente, dever-se-ia dizer que estes eleitores são os que veriam como mais justificáveis (em um maior número de circunstâncias) eventuais golpes militares. A expressão "apoio" tem aqui este sentido.

21 Quase todas as tabelas apresentadas ao longo do texto agrupam os partidos segundo seu posicionamento ideológico. Embora não seja possível apresentar dados individualizados para cada partido, pelo menos no que se refere ao PT são apresentados, nas Tabelas Anexas 4 e 5, dados das correlações entre as "preferências" por este partido e as opiniões políticas dos eleitores no primeiro e no último survey, de forma a permitir o contraste. Mesmo operacionalizando a "preferência" como dicotômica ("com" e "sem"), utilizamos o coeficiente Gama (no lugar do coeficiente de contingência), de forma a deixar claro o sentido (positivo ou negativo) da associação.
} 


\section{Comparação entre os quatro surveys}

Uma primeira comparação é realizada a partir do índice de autoritarismo, por ser o único que capta opiniões relativas a uma dimensão semelhante da opinião do eleitorado (relativa ao grau de controle do Estado sobre as manifestações da sociedade) (Tabela 9).

\section{Tabela 9 - Correlação entre índice de autoritarismo (relativo ao grau de controle do Estado sobre a sociedade) e sentimentos partidários dos eleitores, 1990, 1997, 2002, 2007}

\begin{tabular}{|l|c|c|}
\hline \multirow{2}{*}{ Ano } & \multicolumn{2}{|c|}{ Sentimento Partidário } \\
\cline { 2 - 3 } & Partido preferido ou que representa o eleitor (1) & Rejeição \\
\hline $\mathbf{1 9 9 0}$ & $0,41^{* *}$ & ND \\
\hline $\mathbf{1 9 9 7}$ & $0,23^{* *}$ & $0,39^{* *}$ \\
\hline $\mathbf{2 0 0 2}$ & $0,39^{* *}$ & $0,13^{* *}$ \\
\hline $\mathbf{2 0 0 7}$ & $\cdot 0,03$ & $\cdot 0,04$ \\
\hline
\end{tabular}

ND = Não há dados sobre rejeição no survey de 1990 .

$\left.{ }^{*}\right)$ coef. sig. nível 0,$05 ;(* *)$ coef. sig. nível 0,01 ; demais coef. não sig. estatisticamente.

(1) Partido preferido (1990 e 1997) ou partido que representa o eleitor (2002 e 2007).

Fontes: Cedec-Datafolha, 1990; Fundação Perseu Abramo, 1997; ESEB, 2002; LAPOP-Brasil, 2007.

Enquanto nos surveys de 1990, 1997 e 2002 os coeficientes de correlação encontrados entre o índice de autoritarismo e os sentimentos partidários (tanto "preferência", quanto rejeição partidária) são positivos e estatisticamente significativos (sendo, na realidade, maiores do que os coeficientes relativos às demais opiniões ou índices, em cada caso), os coeficientes encontrados em 2007 são praticamente nulos. Ou seja, com base no índice que permite maior comparabilidade entre os diferentes surveys, destaca-se a diferença entre o de 2007 e os demais ${ }^{22}$.

Mas, a comparação mais completa é feita na Tabela 10, que quantifica a proporção (sobre o total de casos analisados) de correlações entre opiniões (ou índices) e sentimentos partidários, em cada um dos quatro surveys, conforme a magnitude e a significância estatística.

\footnotetext{
22 E é importante ressaltar que os baixos coeficientes de correlação encontrados para 2007 não podem ser debitados ao relativamente pequeno número de casos que acabou permanecendo na análise, já que os coeficientes de correlação não dependem do tamanho da amostra.
} 


\section{Tabela 10 - Porcentagem sobre total de casos de correlações entre opiniões e sentimentos partidários, conforme magnitude e significância estatística das correlações, 1990, 1997, 2002, 2007}

\begin{tabular}{|c|c|c|c|c|c|}
\hline \multirow{2}{*}{$\begin{array}{l}\text { Sentido da } \\
\text { correlação }\end{array}$} & \multirow{2}{*}{$\begin{array}{c}\text { Magnitude e nível de } \\
\text { significância estatística das } \\
\text { correlações }\end{array}$} & \multicolumn{4}{|c|}{ Ano } \\
\hline & & 1990 & 1997 & 2002 & 2007 \\
\hline \multirow{3}{*}{ Positivo } & $\begin{array}{l}\text { Estatist. não significativa } \geq, 10^{*} \text {; } \\
\text { ou Estatist. significativa } \leq 0,20\end{array}$ & 13 & 29 & 29 & 18 \\
\hline & Estatist. significativa $>0,20$ & 53 & 17 & 14 & 5 \\
\hline & Total $(\%)$ & 66 & 46 & 43 & 23 \\
\hline \multirow{3}{*}{ Negativo } & $\begin{array}{l}\text { Estat. não sign. } \geq 0,10 ; \text { ou } \\
\text { Estatist. significativa } \leq 0,20\end{array}$ & 0 & 0 & 0 & 9 \\
\hline & Estatist. significativa $>0,20$ & 0 & 0 & 0 & 14 \\
\hline & Total (\%) & 0 & 0 & 0 & 23 \\
\hline \multicolumn{2}{|r|}{$\mathrm{N}^{\circ}$ total de casos $(\mathrm{N})^{* * *}$} & $(15)$ & (24) & $(14)$ & $(22)$ \\
\hline
\end{tabular}

*Como nos surveys de 1997 e 2007 as amostras (ou subamostras a que foram aplicadas as questões em estudo) eram menores do que em 1990 e 2002, isso pode afetar a probabilidade de significância. Dessa forma, optamos por considerar também as correlações estatisticamente não significativas, mas com coeficiente maior do que 0,10. Foram 5 em 1997 e 2 em 2007.

* $\mathrm{N}^{\circ}$ total de casos = número de cruzamentos entre opiniões (ou índices) e sentimentos partidários (positivos e negativos).

Fontes: Cedec-Datafolha, 1990; Fundação Perseu Abramo, 1997; ESEB, 2002; LAPOP-Brasil, 2007.

Dos 15 "casos" analisados em 1990, em 8 (53\% dos casos) tivemos coeficientes de correlação estatisticamente significativos e de magnitude superior a 0,20 e em outros 2 ( $13 \%$ dos casos) os coeficientes eram estatisticamente significativos, mas abaixo de 0,2023. Em 1997, dos 24 "casos" analisados, em $17 \%$ (4 casos) os coeficientes foram estatisticamente significativos e de magnitude superior a 0,20; em outros $29 \%$ os coeficientes eram estatisticamente significativos, mas abaixo de 0,20, ou estatisticamente não-significativos, mas acima de 0,10. Em 2002, dos 14 casos analisados, em 14\% (2 casos) os coeficientes foram estatisticamente significativos e de magnitude superior a 0,20; em outros $29 \%$ (4 casos) os coeficientes eram estatisticamente significativos, mas abaixo de 0,20. Todas estas correlações ocorreram no sentido teoricamente aqui esperado. Por fim, em 2007, dos 22 casos analisados, em 5\% (1 caso) o coeficiente foi estatisticamente significativo e de magnitude superior a 0,20 ; em outros $18 \%$ (4

\footnotetext{
23 Em 1990 foram correlacionadas 15 diferentes opiniões (incluindo o índice de autoritarismo) com preferência partidária; em 1997 foram correlacionadas 14 diferentes opiniões com preferência partidária e 10 opiniões com rejeição partidária (porque tanto a pergunta referente a este último sentimento partidário, quanto a várias opiniões foram empregadas apenas a uma parte da amostra, de forma que em alguns casos o cruzamento entre as variáveis resultava num conjunto vazio); em 2002, a "preferência" e a rejeição partidárias foram cruzadas com 7 índices, resultando em 14 "casos"; em 2007 foram 11 índices, resultando em 22 casos.
} 
casos) os coeficientes eram estatisticamente significativos, mas abaixo de 0,20, ou estatisticamente não-significativos, mas acima de 0,10. Por outro lado, há $23 \%$ dos casos em que a correlação é negativa, ou seja, em sentido inverso ao teoricamente esperado, sendo duas delas com coeficiente superior a - 0,20. A tendência mais geral é de declínio das correlações positivas estatisticamente significativas e de maior magnitude (maiores que 0,20) ao longo do tempo, chegando a ocorrer correlações negativas de certa magnitude no survey de 2007.

\section{Considerações finais}

O estudo aqui realizado tem várias limitações de ordem metodológica: além das limitações apontadas no início, relacionadas ao fato de não contarmos com estudos de painel, e de fazermos uma análise bivariada (apenas correlacionando cada sentimento partidário com cada opinião, ou índice), devem-se acrescentar outras, devidas às grandes diferenças dos surveys: as amostras são de tamanhos diferentes, em algumas pesquisas, algumas questões foram aplicadas a apenas parte da amostra, o que afeta o cálculo da probabilidade de significância das estatísticas apresentadas ${ }^{24}$. Além disso, as questões usadas variam de um survey a outro (no que se refere aos sentimentos partidários, às opiniões políticas e ao autoposicionamento ideológico dos eleitores). É um conjunto bastante importante de problemas, que limita o alcance das conclusões aqui tiradas. De toda forma, ainda que precisem ser estudados com base em dados e metodologia mais adequados, alguns achados do presente estudo merecem ser destacados:

$1^{\circ}$ ) A magnitude da grande maioria das correlações encontradas parece indicar que, em relação a muitos assuntos, as diferenças de opinião de grande parte dos eleitores que manifestam sentimentos em relação a diferentes partidos não são muito acentuadas. Especialmente no início do período estudado, porém, foram encontradas diferenças substantivas em relação a certas opiniões (detalhadas a seguir);

$2^{\circ}$ ) Consideradas estas ressalvas, há indícios que suportam a hipótese norteadora do trabalho: a) no que se refere à identificação ideológica, os "eleitores petistas" e os "eleitores peessedebistas", que em 1990 posicionavam-se claramente à esquerda e ao centro, respectivamente (em relação ao conjunto do eleitorado), vão progressivamente, mas especialmente em 2007, indiferenciando-se do conjunto do

\footnotetext{
${ }^{24}$ De toda forma, deve ser destacado que, em 1997, como as perguntas sobre opinião política foram, em sua grande maioria, aplicadas a apenas parte da amostra, isso resultou em cruzamentos com os sentimentos partidários com relativamente baixos números de casos, mas, comparativamente, isso não levou a um percentual menor de correlações estatisticamente significativos do que em 2002, em que o número de casos resultantes de cruzamentos semelhantes eram bem maiores (compare-se, por exemplo, as Tabelas 8 e 10).
} 
eleitorado; b) quanto às opiniões políticas dos eleitores, há uma tendência de declínio das correlações positivas (especialmente as de maior magnitude) com os sentimentos partidários, ao longo do tempo. O contraste entre 1990 e 2007 é muito nítido: em 1990, havia maior preferência por partidos à esquerda entre eleitores mais democráticos, igualitários, participativos ou liberais (em questões morais). Em 2007, as opiniões dos eleitores têm muito pouca associação com o partido que preferem ou rejeitam, ou, quando há associação, pode haver associação com algumas opiniões no "sentido esperado".

Em suma, se, em 1990, os eleitores com preferência por diferentes partidos distinguiam-se razoavelmente entre si no que se refere ao seu auto-posicionamento ideológico e suas opiniões políticas, ao final do período estas diferenças são muito pequenas e não têm um sentido único.

Em parte esta variação parece estar associada às mudanças no perfil do eleitorado com "preferência" 25 pelo PT, o partido com identificação mais nítida junto aos eleitores brasileiros. Este eleitorado, ao final do período aqui estudado, tem menor peso do sudeste e maior do nordeste; menor peso dos eleitores com maior nível de instrução e maior peso dos menos instruídos. Esta mudança de perfil deve-se, parcialmente, à "saída" de uma parte do eleitorado petista mais ideológico - face àqueles sinais de menor consistência ideológica e de menor consideração pela ética, nos comportamentos partidários - e parcialmente à "entrada" de um eleitor mais pobre e menos escolarizado, por conta dos resultados positivos da gestão do governo Lula, especialmente das políticas econômica e social. Assim, os sinais emitidos pelos partidos, no sentido de uma maior indiferenciação ideológica, acabam impactando as preferências partidárias, fazendo com que as diferenças mais nítidas (em termos de perfis socioeconômicos e em termos das opiniões políticas) existentes entre os "eleitores partidários" no início do período estudado se diluam.

\footnotetext{
${ }^{25}$ O termo "preferência", aqui, inclui as diferentes manifestações de sentimentos positivos em relação ao partido, mencionadas ao longo do estudo. É provável que tenha havido também um mudança no perfil do eleitor com rejeição pelo PT.
} 


\section{Referências Bibliográficas}

ALMEIDA, A. "Ideologia e comportamento eleitoral: evidências de que a ideologia não é importante para explicar o voto". Paper apresentado ao XXV Encontro Anual da ANPOCS. Caxambu, 2001.

Record, 2007.

. (com a colaboração de Clifford Young). A cabeça do brasileiro. Rio de Janeiro:

BALBACHEVSKY, E. "Identidade Partidária e Instituições Políticas no Brasil". Lua Nova, São Paulo, n²6, 1992.

CARREIRÃO, Y. A decisão de voto nas eleições presidenciais brasileiras. Rio de Janeiro/Florianópolis: Editora da FGV/EDUFSC, 2002.

. "Ideologia e partidos políticos: um estudo sobre coligações em Santa Catarina".

Opinião Pública. Campinas, vol.12, n¹, 2006.

"Relevant factors for the voting decision in the 2002 presidential election: an analysis of the ESEB (Brazilian Electoral Study) Data". Brazilian Political Science Review, vol. $1, \mathrm{n}^{\circ} 1, \mathrm{p} .70 \cdot 101,2007$.

CARREIRÃO, Y. e KINZO, M. D’ALVA. "Partidos políticos, preferência partidária e decisão eleitoral no Brasil (1989/2002)”. Dados. Rio de Janeiro, vol.47, n¹, 2004.

CARREIRÃO, Y. e BARBETTA, P. "A eleição presidencial de 2002: a decisão de voto na região da Grande São Paulo". Revista Brasileira de Ciências Sociais, São Paulo, n56, 2004.

CASTRO, M. M. M. Determinantes do Comportamento Eleitoral: A Centralidade da Sofisticação Política. Tese de Doutorado. IUPERJ, 1994.

CERVI, E. U. Opinião pública e política no Brasil. Tese de Doutorado. IUPERJ, 2006.

KINZO, M. D’ALVA. "A Eleição Presidencial de 1989: o Comportamento Eleitoral em uma Cidade Brasileira". Dados, Rio de Janeiro, vol.35, n 1992.

LAMOUNIER, B. (org.). Ouvindo o Brasil. Uma análise da opinião pública brasileira hoje. São Paulo: Sumaré/IDESP, 1992. 
MENEGUELLO, R. "Electoral Behavior in Brazil: the 1994 Presidential Election". International Social Science Journal, n¹46, 1995.

METENHEIM, K. V. The Brazilian voter: mass politics in democratic transition (1974-86). Pittsburgh/London: University of Pittsburgh Press, 1995.

NICOLAU, J. "An analysis of the 2002 presidential elections using logistic regression". Brazilian Political Science Review, vol.1, n¹, p.125-135, 2007.

PAIVA, D.; BRAGA M. S. e PIMENTEL, J. "Eleitorado e partidos políticos no Brasil”. Opinião Pública. Campinas, vol.13, n², 2007.

PIERUCCI, F. “As bases da nova direita”. Novos Estudos, CEBRAP, n¹9, 1987. . Linguagens autoritárias, voto popular. In: DAGNINO, E. (org.). Anos 90: política e sociedade no Brasil. São Paulo: Brasiliense, 1994.

PIERUCCI, F. e LIMA, M. “A direita flutuante”. Novos Estudos, CEBRAP, n²9, 1991.

RENNÓ, L. "Escândalos e voto: as eleições presidenciais brasileiras de 2006". Opinião Pública. Campinas, vol.13, n², 2007.

SANTOS, F. Governos de coalizão no sistema presidencial. In: AVRITZER, L. e ANASTÁSIA, F. Reforma política no Brasil. Belo Horizonte: Ed. UFMG, 2006.

SILVEIRA, F. A decisão de voto no Brasil. Porto Alegre: EdipucRS, 1998.

SINGER, A. Esquerda e direita no eleitorado brasileiro. São Paulo: Edusp, 2000.

VEIGA, L. "Os partidos brasileiros na perspectiva dos eleitores: mudanças e continuidades na identificação partidária e na avaliação das principais legendas após 2002". Opinião Pública. Campinas, vol.13, n², 2007.

VENTURI, G. “A opinião pública diante da crise”. Teoria e Debate, n66, 2006. 


\section{Apêndices Metodológicos - criação dos índices}

Cada índice foi criado recodificando as respostas às questões que compunham uma mesma dimensão da opinião dos eleitores (dando valores adequados a cada resposta e eliminando as respostas "não sabe", "não respondeu"). Antes de formar cada índice foi feito o teste do Alpha de Cronbach, para verificar sua consistência (ou seja, verificar se as respostas "mediam" efetivamente uma mesma dimensão da opinião). Em caso positivo, as respostas foram somadas, de maneira a formar o índice, que depois foi finalmente recodificado, dividindo a amostra em três grupos (com índice baixo, médio e alto), compostos, cada um, de cerca de um terço da amostra.

\section{Apêndice Metodológico 1 - Operacionalização do índice de autoritarismo (survey USP- Cedec-Datafolha 1990)}

(1) Índice de autoritarismo (dimensão: Estado x sociedade):

Pergunta: "Você concorda ou discorda que o governo":

a) use a polícia contra manifestações de rua?

b) processe quem for contra sua autoridade?

c) faça leis que proíbam manifestações de protesto?

d) use tropas para acabar com greve?

Recodificação: discorda $=0$; depende $=0,5$; concorda $=1$;

Índice recodificado: Baixo $=0$ a 0,5; Médio $=1$ a 2; Alto = 2,5 a 4;

Análise de confiabilidade: Alpha: 0,74. Correlações entre itens: entre 0,32 e 0,49.

\section{Apêndice Metodológico 2 - Operacionalização do índice de autoritarismo (survey Fundação Perseu Abramo 1997)}

(1) Índice de autoritarismo (dimensão: Estado x sociedade):

Pergunta: "Você é a favor ou contra que o governo brasileiro possa ter o direito de":

a) proibir greves?

b) intervir nos sindicatos?

c) proibir a existência de algum partido?

d) censurar jornais, TVs e rádio?

e) fechar o Congresso Nacional?

Recodificação: A favor, totalmente $=1 ;$ A favor, em parte $=0,75$; Contra, em parte $=0,25$; Contra, totalmente $=0$;

Análise de confiabilidade: Alpha: 0,65. Correlações entre 0,18 e 0,39;

Índice recodificado: Baixo $=0$ a 0,5; Médio $=0,75$ a 1,5; Alto $=1,75$ a 5 . 
CARREIRÃO, Y. S. Opiniões políticas e sentimentos partidários...

\section{Apêndice Metodológico 3 - Operacionalização dos índices relativos ao ESEB 2002}

3.1) Índice de Clientelismo: foram incluídas 7 questões (93;95; 97; 99; 101;103 e104), que indagam, p/ex.: "Um candidato oferece uma cadeira de rodas para um deficiente físico. 0 que ele deveria fazer: 1) aceitar a cadeira de rodas e votar no candidato, ou 2) não aceitar a cadeira e votar em outro candidato". O mesmo é feito em relação a outros itens.

Recodificação: 1 = 1; outras respostas = 0;

Análise de confiabilidade: Alpha: 0,89. Correlações entre os itens são todas positivas;

Índice recodificado: Baixo (0 ou 1); Médio (2 a 4); Alto (5 a 7).

3.2) Índice "Rouba-Mas-Faz": (a partir das frases da questão105): a) "em geral, políticos muito honestos não sabem governar"; b) "não faz diferença se um político rouba ou não, o importante é que ele faça as coisas de que a população precisa"; c) "é melhor um político que faça muitas obras, mesmo que roube um pouco, do que um político que faça poucas obras e não roube nada"; d) "existem alguns políticos que são honestos"; e) "é possível fazer obras públicas sem roubar"; f) "político honesto não tem sucesso na política"; g) "um político que faz muito e que rouba um pouco merece o voto da população"; h) "políticos muito honestos prejudicam o funcionamento do governo"; i) "um político que faz um bom governo deve poder desviar dinheiro público para financiar sua campanha eleitoral"; j) "é melhor resolver rapidamente um problema da população, mesmo que para isso seja preciso pagar por fora"; k) "todos os políticos roubam".

Recodificação: - itens a/b/c/f/g/h/i/j/k - respostas "concorda" (um pouco; muito) = 1 ; respostas "discorda" (um pouco; muito) ou "nem concorda nem discorda" =0;

- itens d/e - respostas "concorda" (um pouco; muito) = 0; respostas "discorda" (um pouco; muito) ou "nem concorda nem discorda" =1;

Análise de confiabilidade: Alpha: 0,74. Correlações entre os itens são todas positivas;

Índice recodificado: Baixo (0 a3); Médio (4 a 6); Alto (7 a 11).

3.3) Índice de Autoritarismo (dimensão: protesto contra o governo): questão111: "agora eu vou mencionar vários tipos de protestos* contra o governo e gostaria que o(a) sr(a). dissesse se o protesto deve sempre ser permitido (1), deve ser permitido na maioria das vezes (2); deve ser proibido na maioria das vezes (3); ou se deve ser sempre proibido (4)". *(abaixo assinado; passeatas; comícios; greves; bloqueio de estradas; ocupação de prédios públicos; ocupação de terras).

Recodificação: respostas $1=0 ; 2=1 ; 3=2 ; 4=3$; outras respostas = missing; Análise de confiabilidade: Alpha: 0,68. Correlações entre os itens são todas positivas; Índice recodificado: Baixo $=0$ a 8; Médio $=9$ a 12; Alto $=13$ a 21 . 
3.4) Índice de regulação do mercado pelo estado: frases da questão 108: a) "o governo deve controlar o preço de todos os serviços básicos, como por exemplo, do transporte"; b) "o governo deve dizer tudo o que as empresas têm que fazer, como por ex., quantos banheiros elas têm que ter"; c) "só as empresas, e nunca o governo, têm que treinar a mão-de-obra"; d) "o governo deve socorrer as empresas em dificuldades"; e) "o governo deve definir qual o valor dos salários de todos os funcionários de todas as empresas do Brasil; f) "só as empresas, e nunca o governo, devem escolher onde construir uma nova fábrica"; g) "o governo deve controlar os preços de todos os produtos vendidos no Brasil";

Recodificação: - itens a / b / d /e / g : 5 (concorda muito) = 2; 2 a 4 (concorda um pouco; nem concorda nem discorda; discorda um pouco) $=1 ; 1$ (discorda muito) =0; outras resp. = missing; - itens c / f: $5=0 ; 2$ a $4=1 ; 1=2$; outras respostas = missing;

Análise de confiabilidade: Alpha: 0,36 (apesar do valor baixo, o índice foi mantido);

Índice recodificado: Baixo $=0$ a 7; Médio $=8$ a 10; Alto $=11$ a 14 .

3.5) Índice de fechamento do mercado para o exterior: frases da questão 109: a) "o governo precisa dificultar mais a entrada de produtos estrangeiros no Brasil"; b) "o governo deve proibir o emprego de trabalhadores estrangeiros no Brasil"; c) "o governo deve permitir que empresas estrangeiras enviem todo o lucro para o exterior"; d) "o governo deve oferecer facilidades para atrair investimentos de grandes empresas estrangeiras para o Brasil"; e) "o governo deve proibir que estrangeiros comprem terras no Brasil"; f) "o governo deve obrigar todas as empresas estrangeiras a irem embora do Brasil". (item g foi retirado; tinhas baixas correlações com outros itens).

Recodificação: - itens a / b / e / f : $5=2 ; 2$ a $4=1 ; 1=0$; outras respostas = missing;

- itens c / d: $5=0 ; 2$ a $4=1 ; 1=2$; outras respostas = missing;

Análise de confiabilidade: Alpha: 0,41 (apesar do valor baixo, o índice foi mantido);

Índice recodificado: Baixo $=0$ a 5 ; Médio $=6$ a 7 ; Alto $=8$ a 14 .

3.6) Índice de liberalismo econômico: frases da questão 107: "Quem deve administrar a/o ; só empresas do governo ou só empresas particulares?" (educação; saúde; previdência social; justiça; transporte; estradas e rodovias; fornecimento de água; serviço de esgoto; recolhimento de lixo; energia elétrica; telefone fixo; celular; bancos; fabricação de carros).

Recodificação: só empresas do governo $=0$; empresas do governo e particulares $=1$; só empresas particulares $=2$;

Análise de confiabilidade: Alpha: 0,84. Correlações entre os itens são todas positivas;

Índice recodificado, para 3 valores: Baixo $=0$ a 4 ; Médio $=5$ a 10; Alto $=11$ a 28 .

\section{7) Índice de conservadorismo moral}

Perguntas: "Vou ler para o sr/sra mais uma série de frases e gostaria que o sr./sra. dissesse se discorda muito (1), discorda um pouco (2), nem concorda nem discorda (3); concorda um pouco (4) ou concorda muito (5): 
P106a) Um programa de TV que defende o casamento de homem com homem a mulher com mulher deve ser proibido;

P106b) Um programa de TV que diz que Deus não existe deve ser proibido;

P106c) Um programa de TV com cenas de violência deve ser proibido";

Obs: p106d foi retirada; tinha baixas correlações com outros itens.

Recodificação: 0 a 5 = valores foram mantidos; outras = missing;

Análise de confiabilidade: Alpha: 0,64 (correlações entre itens: 0,31 a 0,44);

Índice recodificado: Baixo (3 a 10); Médio (11 a 14); Alto (15).

\section{Apêndice Metodológico 4 - Operacionalização dos índices relativos ao LAPOP (2007)}

4.1) Índice de Autoritarismo 1 (dimensão: grau de controle do Estado sobre a sociedade)

Pergunta: "Agora vamos falar de algumas ações que o Estado pode tomar. Continuaremos usando uma escala de um a dez. Nesta escala 1 significa que o(a) sr(a). desaprova totalmente e o 10 significa que aprova totalmente." "Até que ponto aprova ou desaprova"

D32: uma lei que proíba os protestos públicos?

D33: uma lei que proíba reuniões de qualquer grupo que critique o sistema político brasileiro?

D34: que o governo censure programas de televisão?

D35: que o governo censure programas de televisão que defendem o casamento de homem com homem e mulher com mulher?

D36: que o governo censure livros que estão nas bibliotecas das escolas públicas?

D37: que o governo censure aos meios de comunicação que o criticam?

Análise de confiabilidade: alpha: 0,72. Correlações entre itens: de 0,17 a 0,55;

Índice recodificado: Baixo (6 a 15); Médio (16 a 25); Alto (26 a 60).

4.2) Índice de Autoritarismo 2 (dimensão: direitos políticos da oposição e das minorias)

Pergunta: "As perguntas abaixo são para saber sua opinião sobre as diferentes idéias que têm as pessoas que vivem no Brasil. Use sempre a escala de 10 pontos": "Existem pessoas que sempre falam mal da forma de governo do Brasil, não somente do governo atual, mas sim da forma de governo. O quanto o(a) sr(a) aprova ou desaprova":

D1) " o direito de votar dessas pessoas?"

D2) "que elas realizem manifestações pacíficas com o propósito de expressar seus pontos de vista?"

D3) "que elas possam candidatar-se para cargos públicos?"

D4) "que elas apreçam na televisão para discursar?"

D5) "E agora, mudando de assunto e pensando nos homossexuais, o quanto o(a) sr(a) aprova ou desaprova que estas pessoas possam candidatar-se para cargos públicos?"

Análise de confiabilidade: alpha: 0,88. Correlações entre itens: de 0,53 a 0,71; 
Índice recodificado: Baixo (5 a 24); Médio (25 a 35); Alto (36 a 50).

4.3) Índice de Autoritarismo 3 (dimensão: grau de apoio a golpes de Estado): Pergunta: "Algumas pessoas dizem que em certas circunstâncias se justificaria que os militares tomassem o poder por um golpe de estado. Na sua opinião em quais circunstâncias que eu vou mencionar se justificaria um golpe militar:"

JC1: "Diante de desemprego muito alto";

JC4: "Diante de muitos protestos sociais";

JC10: "Quando há muito crime"

JC12: "Diante de inflação alta, com aumento excessivo de preços";

JC13: "Diante de muita corrupção".

Respostas recodificadas: 1 : "seria justificado" $=1$; outras respostas $=0$;

Análise de confiabilidade: alpha: 0,94. Correlações entre itens: de 0,68 a 0,79;

Índice recodificado: Baixo (zero); Médio (1 a 2); Alto (3 a 5).

\section{4) Índice de Participacionismo}

Pergunta: "Este cartão tem uma escala de 10 pontos, sendo que o 1 indica que o(a) sr(a). desaprova totalmente e o 10 indica que aprova totalmente. Vou ler uma lista de algumas ações ou coisas que as pessoas podem fazer para atingir suas metas e objetivos políticos. Quero que me diga o quanto o(a) sr(a). aprovaria ou desaprovaria as seguintes ações":

E5: "a participação de pessoas em manifestações permitidas por lei";

E8: "a participação de pessoas em uma organização ou grupo para resolver os problemas da comunidade";

E11: "o trabalho de pessoas em campanhas eleitorais para um partido político ou candidato".

Análise de confiabilidade: alpha: 0,70. Correlações entre itens: de 0,37 a 0,59;

Índice recodificado: Baixo (3 a 17); Médio (18 a 23); Alto (24 a 30).

(Obs: as perguntas E15, E14 e E2 mostraram ter coeficientes de correlação muito baixos ou negativos com as questões usadas neste índice, por isso, não foram incluídas).

\section{5) Índice de Radicalismo Político}

Pergunta: "Este cartão tem uma escala de 10 pontos, sendo que o 1 indica que o(a) sr(a). desaprova totalmente e o 10 indica que aprova totalmente. Vou ler uma lista de algumas ações ou coisas que as pessoas podem fazer para atingir suas metas e objetivos políticos. Quero que me diga o quanto o(a) sr(a). aprovaria ou desaprovaria as seguintes ações":

E15: "a participação de pessoas em bloqueios de ruas ou rodovias";

E14: "a invasão de propriedades ou terrenos privados";

E2: "a ocupação de fábricas, escritórios ou outros edifícios";

E3: "a participação de pessoas em um grupo para derrubar um governo eleito por meios violentos"; 
E16: "as pessoas fazerem justiça com as próprias mãos quando o Estado não castiga os criminosos".

Análise de confiabilidade: alpha: 0,79. Correlações entre itens: de 0,32 a 0,71;

Índice recodificado: Baixo (5 a 9); Médio (10 a16); Alto (17 a 50).

\section{6) Índice de apoio à concentração do poder político (nas mãos do presidente da República)}

Pergunta: "Levando em conta a situação atual do país me diga com qual das seguintes frases o sr/sra concorda mais:

POP1. 1. Para que o país tenha progresso, é necessário que nossos presidentes limitem a voz e o voto dos partidos da oposição, [ou ao contrário]; 2. Mesmo que o progresso do país se atrase, nossos presidentes não devem limitar a voz e o voto dos partidos da oposição.

POP2. 1. O Congresso impede muito o trabalho de nossos presidentes, e deveria ser ignorado; 2. Mesmo que atrapalhe o trabalho do presidente, nossos presidentes não deveriam passar por cima do Congresso.

POP3. 1. Os juízes atrapalham, com freqüência, o trabalho de nossos presidentes, e deveriam ser ignorados; 2 Mesmo que, às vezes, os juízes atrapalhem o trabalho de nossos presidentes, as suas decisões têm de ser sempre obedecidas.

POP4. 1. Nossos presidentes devem ter o poder necessário para atuar a favor do interesse nacional; 2. O poder de nossos presidentes deve ser limitado para que nossa liberdade não corra perigo.

POP5. 1. Nossos presidentes devem fazer o que o povo quer, mesmo que as leis os impeçam; 2. Nossos presidentes devem obedecer às leis, mesmo que o povo não goste".

Recodificação: Resp.1 = 1; Resp. 2 = 0; NS/NR = 0 .

Análise de confiabilidade: alpha: 0,87. Correlações entre itens: de 0,53 a 0,63;

Índice recodificado: Baixo (zero); Médio (1 e 2); Alto (3 a 5).

\section{7) Índice de liberalismo econômico}

Perguntas: "Vou ler para o sr/sra mais uma série de frases e gostaria que o sr./sra. dissesse se discorda muito (1), discorda (2), concorda (3) ou concorda muito (4):

PR1: As leis e os impostos do governo impedem as empresas de terem lucros

PR2: A privatização das empresas estatais foi boa para o país

PR3: É preciso dar mais liberdade para as empresas despedirem os empregados

PR7: O governo deveria oferecer menos serviços públicos, como saúde e educação, para reduzir os impostos.

PR9: Quanto menos o governo interferir na economia, melhor para o país".

Recodificação: $1=0 ; 2=0,5 ; 3=1 ; 4=2$; demais resp. = missing;

Índice varia de 0 a 10, mas foi recodificado, de forma a dividir a amostra em três grupos de tamanho semelhante: Baixo (0 a 2); Médio (2,5 a 3,5); Alto (4 a 10);

Análise de confiabilidade: correlações entre itens variando de 0,16 a 0,38; alfa de Cronbach: 0,62 . 


\section{8) Índice de igualitarismo:}

Perguntas: "Vou ler para o sr/sra mais uma série de frases e gostaria que o sr./sra. dissesse se discorda muito (1), discorda (2), concorda (3) ou concorda muito (4):

PR4: O Brasil estaria bem melhor se nós nos preocupássemos menos com que todo mundo seja igual.

PR5: Nós teríamos menos problemas no Brasil se as pessoas fossem tratadas com mais igualdade.

PR6: Em um país como o Brasil, é obrigação do governo diminuir as diferenças entre os muito ricos e os muito pobres.

PR8: Se o país for rico, não importa que haja muitas desigualdades econômicas e sociais". Recodificação: PR4 e PR8: $1=2 ; 2=1 ; 3=0,5 ; 4=0$; demais respostas = missing;

PR5 e PR6: $1=0 ; 2=0,5 ; 3=1 ; 4=2$; demais respostas = missing;

Análise de confiabilidade: correlações entre itens variando de 0,06 a 0,57; alfa de Cronbach: 0,43. (Obs: mesmo com estes dados indicando que o índice não é dos mais adequados, resolvemos mantê-lo);

Índice recodificado: Baixo (0 a 4); Médio (4,5 a 5,5); Alto (6 a 8).

\section{9) Índice de conservadorismo moral (com respeito a gênero)}

Perguntas: "Vou ler para o sr/sra mais uma série de frases e gostaria que o sr./sra. dissesse se discorda muito (1), discorda (2), concorda (3) ou concorda muito (4):

GEN3: No geral, homens são mais adequados para a carreira política do que mulheres.

GEN4: No geral, quando eleitos, homens governam melhor do que mulheres.

GEN5: As mulheres ainda não tem experiência política suficiente para governar bem.

GEN6: Quando o desemprego é elevado, os homens deveriam ter mais direito ao trabalho do que as mulheres.

GEN7: Um diploma universitário é mais essencial aos homens do que às mulheres".

Recodificação: GEN3 a GEN7: $1=0 ; 2=0,5 ; 3=1 ; 4=2$; demais respostas = missing;

Análise de confiabilidade: alpha: 0,88. Correlações entre itens: de 0,49 a 0,76;

Índice recodificado: Baixo (0); Médio (0,5 a 2); Alto (2,5 a 10).

\subsection{0) Índice de Clientelismo (Perguntas: RMF1 a RMF7)}

"Eu vou ler várias situações e gostaria que o(a) $\operatorname{Sr}(a)$ dissesse o que cada pessoa deveria fazer:

RMF1: Um candidato oferece uma cadeira de rodas para um deficiente físico, o que ele deveria fazer: 1 Aceitar a cadeira de rodas e votar no candidato OU 2 Não aceitar a cadeira e votar em outro candidato? 8 NS 9 NR;

As demais questões são semelhantes, substituindo a cadeira de rodas por outro "bem":

RMF2: cesta básica de alimentos para família muito pobre;

RMF3: matrícula para filho na escola;

RMF4: dinheiro para o tratamento médico de filho doente; 
RMF5: caminhão de tijolos para construir casa;

RMF6: campo de futebol para amigos que jogam junto;

RMF7: bicicleta para uma criança (o que os pais deveriam fazer)?"

Recodificação: $1=1 ; 2=0$; outras respostas = missing;

Análise de confiabilidade: alpha: 0,90. Correlações entre itens: de 0,44 a 0,67;

Índice recodificado: Baixo (0 a 2); Médio (3 a 6); Alto (7).

\subsection{1) Índice "Rouba mas faz" (RM8 aRM10; RM13 a RM17)}

Perguntas: "Vou ler para o sr/sra mais uma série de frases e gostaria que o sr./sra. dissesse se discorda muito (1), discorda (2), concorda (3) ou concorda muito (4):

RM8: Em geral, políticos muito honestos não sabem governar.

RM9: Não faz diferença se um político rouba ou não, o importante é que ele faça as coisas de que a população precisa.

RM10: É melhor um político que faça muitas obras, mesmo que roube um pouco, do que um político que faça poucas obras e não roube nada.

RM13: Político honesto não tem sucesso na política.

RM14: Um político que faz muito e que rouba um pouco merece o voto da população.

RM15: Políticos muito honestos prejudicam o funcionamento do governo.

RM16: Um político que faz um bom governo deve poder desviar dinheiro público para financiar sua campanha eleitoral.

RM17: É melhor resolver rapidamente um problema da população, mesmo que para isso seja preciso pagar por fora".

Recodificação: $1=0 ; 2=0,5 ; 3=1 ; 4=2$; outras respostas = missing;

Análise de confiabilidade: alpha: 0,74. Correlações entre itens: de 0,07 a 0,52;

Índice recodificado: Baixo (0 a 2,5); Médio (3 a 5,5); Alto (6 a 16). 
Tabelas anexas

Tabela Anexa 1 - Preferências pelos principais partidos, segundo o índice de autoritarismo dos eleitores, 1990 (\%)

\begin{tabular}{|c|c|c|c|c|c|}
\hline \multirow{2}{*}{$\begin{array}{l}\text { Posicionamento } \\
\text { ideológico do } \\
\text { partido }\end{array}$} & \multirow{2}{*}{$\begin{array}{l}\text { Preferência } \\
\text { Partidária }\end{array}$} & \multicolumn{4}{|c|}{ Índice de autoritarismo } \\
\hline & & Baixo & Médio & Alto & Total \\
\hline \multirow{3}{*}{ Direita } & PDS & 3 & 6 & 7 & 5 \\
\hline & PFL & 2 & 5 & 5 & 4 \\
\hline & PRN & 5 & 9 & 9 & 8 \\
\hline \multirow{2}{*}{ Centro } & PMDB & 9 & 10 & 14 & 11 \\
\hline & PSDB & 4 & 2 & 1 & 2 \\
\hline \multirow{2}{*}{ Esquerda } & PDT & 6 & 5 & 2 & 4 \\
\hline & PT & 17 & 9 & 2 & 10 \\
\hline \multicolumn{2}{|c|}{ Outras situações* } & 54 & 54 & 60 & 57 \\
\hline \multicolumn{2}{|c|}{$(\mathrm{N})$} & $(727)$ & $(818)$ & $(623)$ & (2168) \\
\hline
\end{tabular}

*Preferência por outros partidos; sem preferência partidária.

Fonte: Cedec-USP.Datafolha, março, 1990.

Tabela Anexa 2 - "Preferências partidárias" dos eleitores, agregadas conforme os posicionamentos ideológicos dos partidos, segundo o índice de apoio à concentração do poder político, 2007 (\%)

\begin{tabular}{|c|c|c|c|c|}
\hline \multirow{2}{*}{$\begin{array}{l}\text { "Preferências partidárias"* } \\
\text { (agregadas conforme os } \\
\text { posicionamentos ideológicos dos partidos) }\end{array}$} & \multicolumn{4}{|c|}{$\begin{array}{c}\text { Índice de apoio à } \\
\text { concentração do poder político }\end{array}$} \\
\hline & Baixo & Médio & Alto & Total \\
\hline Esquerda & 61 & 70 & 76 & 69 \\
\hline Centro & 26 & 24 & 16 & 22 \\
\hline Direita & 13 & 7 & 8 & 9 \\
\hline$(N)$ & (97) & (164) & $(101)$ & (362) \\
\hline
\end{tabular}

Gama $=-0,21$ (Sig.: 0,020). * "Partido que representa como o eleitor pensa".

Fonte: LAPOP.Brasil, 2007.

Tabela Anexa 3 - "Preferências partidárias" dos eleitores, agregadas conforme os posicionamentos ideológicos dos partidos, segundo o índice de autoritarismo 3 (apoio a golpes de Estado), 2007 (\%)

\begin{tabular}{|l|c|c|c|c|}
\hline $\begin{array}{l}\text { "Preferências partidárias" } \\
\text { (agregadas conforme os } \\
\text { posicionamentos ideológicos dos } \\
\text { partidos) }\end{array}$ & \multicolumn{4}{|c|}{$\begin{array}{l}\text { Índice de autoritarismo 3 } \\
\text { (apoio a golpes de Estado) }\end{array}$} \\
\cline { 2 - 5 } & Baixo & Médio & Alto & Total \\
\hline Esquerda & 66 & 74 & 78 & 71 \\
\hline Centro & 23 & 20 & 15 & 20 \\
\hline Direita & 11 & 6 & 7 & 9 \\
\hline$(\mathrm{N})$ & $(155)$ & $(84)$ & $(94)$ & $(333)$ \\
\hline
\end{tabular}

Gama $=\cdot 0,20$ (Sig.: 0,035).

Fonte: LAPOP-Brasil, 2007. 
Tabela Anexa 4 - Correlações entre opiniões políticas e preferência pelo PT, 1990

\begin{tabular}{|l|c|}
\hline \multicolumn{1}{|c|}{ Opiniões Políticas } & Correlação \\
\hline Índice de Autoritarismo (Estado x sociedade) & $0,52^{* *}$ \\
\hline Democracia x ditadura & 0,02 \\
\hline Minoria deve obedecer & $0,24^{* *}$ \\
\hline Mudanças: líder x participação popular & $0,32^{* *}$ \\
\hline Volta militares ao poder & $0,32^{* *}$ \\
\hline Mudanças só com violência & 0,00 \\
\hline Socialismo é solução dos problemas sociais & 0,02 \\
\hline É bobagem mudar leis, porque elas não são respeitadas & 0,05 \\
\hline Manter família x acabar casamento infeliz & $0,30^{* *}$ \\
\hline Proteger pobres prejudica quem trabalha & $0,28^{* *}$ \\
\hline No capitalismo quem se esforça fica rico & $0,29^{* *}$ \\
\hline Seria melhor se só existisse um partido & $0,34^{* *}$ \\
\hline Ajudar os pobres é com ajuda do governo & $0,22^{* *}$ \\
\hline Só deveriam votar as pessoas com estudo & $0,15^{*}$ \\
\hline País rico não importa desigualdade social & $0,35^{* *}$ \\
\hline
\end{tabular}

Fonte: CEDEC-USP-Datafolha, março, 1990.

Tabela Anexa 5 - Correlações entre opiniões políticas e Preferência pelo PT(*), 2007

\begin{tabular}{|l|c|c|c|c|}
\hline $\begin{array}{l}\text { Índices } \\
\text { (que sintetizam opiniões políticas) }\end{array}$ & Correlação & Baixo & Médio & Alto \\
\hline $\begin{array}{l}\text { Autoritarismo 1 } \\
\text { (controle do Estado sobre a sociedade) }\end{array}$ & 0,10 & 13 & 18 & 17 \\
\hline $\begin{array}{l}\text { Autoritarismo 2 } \\
\text { (direitos políticos da oposição e das minorias) }\end{array}$ & $0,20^{* *}$ & 20 & 16 & 12 \\
\hline $\begin{array}{l}\text { Autoritarismo 3 } \\
\text { (apoio a golpes de Estado) }\end{array}$ & $-0,16^{*}$ & 15 & 15 & 23 \\
\hline Liberalismo econômico & 0,13 & 21 & 16 & 15 \\
\hline Conservadorismo Moral & $-0,03$ & 16 & 17 & 17 \\
\hline Clientelismo & 0,06 & 16 & 19 & 14 \\
\hline "Rouba, mas faz" & 0,12 & 21 & 16 & 16 \\
\hline Apoio à Concentração do Poder Político & $-0,25 * *$ & 11 & 16 & 22 \\
\hline Radicalismo & 0,06 & 15 & 18 & 17 \\
\hline Participacionismo & 0,06 & 16 & 15 & 18 \\
\hline Igualitarismo & 0,10 & 15 & 17 & 15 \\
\hline
\end{tabular}

(*) Partido que representa o eleitor; ND = Não há dados.

Fonte: LAPOP-Brasil, 2007.

Yan de Souza Carreirão - yan@cfh.ufsc.br

Recebido e aprovado para publicação em agosto de 2008. 